\title{
Validation of a Method for Analysis of Aroma Compounds in Red Wine using Liquid-Liquid Extraction and GC-MS
}

\author{
Violeta Ivanova $\cdot$ Marina Stefova $\cdot$ Trajče Stafilov • \\ Borimir Vojnoski • Ildiko Bíró • Anita Bufa • \\ Ferenc Kilár
}

Received: 3 December 2011 / Accepted: 9 March 2012 /Published online: 23 March 2012

(C) Springer Science+Business Media, LLC 2012

\begin{abstract}
An analytical method for determination of volatile composition of wines using sample preparation by liquidliquid extraction and gas chromatography coupled to mass spectrometry for separation and detection has been developed and validated. Extraction of volatile compounds was performed in dichloromethane, and 1-octanol was added as an internal standard. Kékfrankos red wine produced in Villány wine region in Hungary was used as a model wine for testing and validation of the method. The developed method allowed satisfactory determination of 33 volatile compounds in the wines. Compounds analyzed include
\end{abstract}

V. Ivanova $(\triangle)$

Faculty of Agriculture, Goce Delčev University of Štip,

Krste Misirkov bb,

2000 Štip, Republic of Macedonia

e-mail: violeta.ivanova@ugd.edu.mk

\section{Stefova $\cdot$ T. Stafilov}

Faculty of Natural Sciences and Mathematics,

Institute of Chemistry, Ss Cyril and Methodius University,

Arhimedova 5, 1000 Skopje,

Republic of Macedonia

\section{B. Vojnoski}

Institute of Agriculture, Department for Enology,

Ss Cyril and Methodius University,

Aleksandar Makedonski bb,

1000 Skopje, Republic of Macedonia

\section{Bíró • A. Bufa • F. Kilár}

Faculty of Medicine, Institute of Bioanalysis, University of Pécs,

Szigeti útja 12,

7624 Pécs, Hungary

\section{F. Kilár}

Faculty of Sciences, Department of Analytical and Environmental Chemistry, University of Pécs,

Ifjúság útja,

7624 Pécs, Hungary alcohols, esters, lactones, fatty acids, furans, and nitrogen compounds. The calibration curves of the four reference compounds used (2-phenyl ethanol, ethyl nonanoate, butyrolactone, and tyrosol) were linear in all cases with correlation coefficients $\left(R^{2}\right)$ ranging from 0.9951 to 0.9992 . The accuracy of the method was checked with a standard addition method (recovery 92.2-103\%), showing good repeatability and reproducibility $(\mathrm{RSD}<10 \%)$.

Keywords GC-MS · Volatile compounds · Wine ·

Method validation $\cdot$ Liquid-liquid extraction .

Dichloromethane $\cdot$ Kékfrankos

\section{Introduction}

Wine aroma, which is one of the most important characteristics for wine quality, represents a good balance of several hundred volatile compounds. Different groups of volatile compounds, such as alcohols, esters, aldehydes, lactones, terpenes, and phenols, have been identified in wines in a wide concentration range, affecting the wine aroma even present in low concentration. Among the volatiles, alcohols and esters are the main compounds present with the highest content in wines. Esters are important constituents of wine aroma, which possess high fruity nuances (Marais and Poll 1980).

Qualitative and quantitative characterizations of volatile compounds in wine are usually performed by GC-MS as one of the most sensitive techniques for analysis of aroma in different samples (Verzera et al. 2008; Andujar-Ortiz et al. 2009; Tang et al. 2011). In addition, the liquid-liquid extraction method using different organic solvents is a very suitable technique for extraction of a wide range of volatile components (Ortega-Heras et al. 2002; Andujar- 
Ortiz et al. 2009). This technique shows high repeatability and possibility of carrying out simultaneous extractions, which is one of its advantages over other solvent-free techniques.

Kékfrankos is a grape variety grown in Hungary, in a number of wine regions such as Villány, Szekszárd, Sopron, and Eger. This variety is usually used for production of notorious red wine blend known as "Bull's Blood", and it is being used for production of a single varietal wine. The same cultivar is also grown in Austria and Germany where it is called Blaufränkisch and Lemberger, respectively, as well as in Croatia, Czech Republic, Slovakia, and Slovenia. However, the origin of this variety has not been determined yet, and therefore, it could be more accurately called "Middle European" variety. The wine from this variety has ruby red color, is rich in tannins, and possesses spicy character and aromas of cherry fruit, blackberries, and currants.

The Kékfrankos wine from Hungary has not been characterized with respect to the volatile composition. Therefore, the aim of the present work was twofold: to develop and validate the liquid-liquid extraction method followed by GC-MS analysis for characterization of the volatile composition of wine and to apply the validated method for characterization of the volatile components making the aroma profile of the local Kékfrankos red wines produced from the grape variety grown in the Villány wine region in Hungary.

\section{Materials and Methods}

\section{Chemicals and Reagents}

The reference standards, 2-phenyl ethanol, ethyl nonanoate, butyrolactone, tyrosol, and 1-octanol (used as an internal standard, IS) were supplied from Fluka (St. Louis, MO, USA). A commercial solution of 24 aliphatic hydrocarbons (C8-C32) in hexane from Supelco (Bellefonte, PA, USA) was used for calculation of the Linear Retention Indices (LRI). Dichloromethane, used for extraction of volatiles, was obtained from Merck (Darmstadt, Germany). The standard stock solutions were prepared by dissolving $10 \mathrm{mg}$ of each reference compound, 2-phenyl ethanol, ethyl nonanoate, butyrolactone, and tyrosol, in $10 \mathrm{~mL}$ of dichloromethane.

\section{Wine Samples}

Five Kékfrankos red wines from different wineries located in the Villány wine region, Hungary, were purchased from the local market in Pécs, Hungary. The wine samples were from vintage, 2008, and they were kept at $4{ }^{\circ} \mathrm{C}$ before analysis.
Liquid-Liquid Extraction

Liquid-liquid extraction was used for isolation of the volatile compounds from the wine samples. Thus, $50 \mathrm{~mL}$ of wine was spiked with $200 \mu \mathrm{L}$ internal standard of 1octanol in hexane with concentration of $500 \mu \mathrm{g} / \mathrm{L}$, and the sample was placed in a glass-capped Erlenmeyer flask. A volume of $25 \mathrm{~mL}$ dichloromethane was added to the spiked wine sample, and the flask was placed in an ice bath, followed by continuous stirring of the mixture for $30 \mathrm{~min}$ on a magnetic stirrer. Then, the mixture was centrifuged at $3,000 \mathrm{rpm}$ for $15 \mathrm{~min}$ at a temperature of $2-4{ }^{\circ} \mathrm{C}$. Once the phases were separated, the dichloromethane layer was evaporated under a nitrogen stream to approximately $200 \mu \mathrm{L}$ volume of the extract and then a volume of $1 \mu \mathrm{L}$ was injected into the GC-MS system. All extractions were carried out in triplicate.

\section{GC-MS Analysis}

Analysis of wine volatile compounds was carried out using an Agilent 5975 Mass Spectrometer coupled to an Agilent 6890 N Gas Chromatograph (Agilent, Santa Clara, USA). The polar capillary column used for separation of the compounds was a Carbowax type from Agilent, with dimensions $30 \mathrm{~m} \times 0.25 \mathrm{~mm}$ ID and $0.25 \mu \mathrm{m}$ film thickness. The working parameters were injector temperature of $240{ }^{\circ} \mathrm{C}$, MS source of $230{ }^{\circ} \mathrm{C}$, MS Quad of $150{ }^{\circ} \mathrm{C}$, and transfer line of $280{ }^{\circ} \mathrm{C}$. The initial temperature was $40{ }^{\circ} \mathrm{C}$ for $3 \mathrm{~min}$ and then rose to $180{ }^{\circ} \mathrm{C}$ at a rate of $3{ }^{\circ} \mathrm{C} / \mathrm{min}$. Then, the temperature was further raised to $260{ }^{\circ} \mathrm{C}$ with $20{ }^{\circ} \mathrm{C} /$ min and kept at $260{ }^{\circ} \mathrm{C}$ for $10 \mathrm{~min}$. The carrier gas was He with a flow rate of $1.5 \mathrm{~mL} / \mathrm{min}$. Samples were injected using the splitless mode. A mass range of 50$400 \mathrm{~m} / \mathrm{z}$ was recorded at one scan per second.

\section{Calibration Curves}

For quantification, five-point calibration curves were constructed for the following standard compounds: 2-phenyl ethanol $(50-15,000 \mu \mathrm{g} / \mathrm{L})$, ethyl nonanoate $(50-$ $20,000 \mu \mathrm{g} / \mathrm{L})$, butyrolactone (100-20,000 $\mu \mathrm{g} / \mathrm{L})$, and tyrosol $(100-5,000 \mu \mathrm{g} / \mathrm{L})$, containing the internal standard (1-octanol). For that purpose, a synthetic wine model sample (12\% ethanol and $4 \mathrm{~g} / \mathrm{L}$ tartaric acid with $\mathrm{pH}$ 3.4 , adjusted by sodium hydroxide solution) was prepared, containing the known amounts of the standards, which was extracted and analyzed by GC-MS as above-mentioned. Extraction of volatile compounds was performed three times for each wine and then each extract was injected into the GC/MS.

In order to quantify the volatile compounds present in the wines, the relative peak area (in the total ion chromatogram) 
of each analyte from the wine to the internal standard was compared to those obtained for the standards, taking into account the dilution of the samples. The concentration of the volatile compounds for which there was no pure reference was obtained using the calibration curve of one of the standard compounds with the most similar chemical structure, i.e., belonging to the same class of compounds.

Validation of the Method

\section{Linearity}

Linearity was tested in 3 days at five concentration levels of 2-phenyl ethanol, ethyl nonanoate, butyrolactone, and tyrosol, containing the internal standard, 1-octanol, in the wine samples.

\section{Limit of Quantification (LOQ)}

LOQ was determined by measuring the signals from the lowest concentration standards of 2-phenyl ethanol ( $50 \mu \mathrm{g} / \mathrm{L})$, ethyl nonanoate $(50 \mu \mathrm{g} / \mathrm{L})$, butyrolactone $(100 \mu \mathrm{g} / \mathrm{L})$, and tyrosol $(100 \mu \mathrm{g} / \mathrm{L})$ in one wine (1) and calculating the standard error. For determination of LOQ, the wine sample spiked with the lowest concentration calibration standards was extracted three times in five analytical days, and errors were also calculated. The quantification of the volatile compounds present in the wine used for validation of the method was performed prior to standard addition.

\section{Recovery}

The recovery of the method was determined by analysis of the wine samples containing three concentration levels: 50, 200, and $500 \mu \mathrm{g} / \mathrm{L}$, for each available standard (2-phenyl ethanol, ethyl nonanoate, butyrolactone, and tyrosol). The concentration of the internal standard, 1-octanol, was constant at $500 \mu \mathrm{g} / \mathrm{L}$. Then, each wine sample for each concentration level of the standards was extracted three times during 1 day.

\section{Repeatability and Reproducibility}

Intraday repeatability and interday reproducibility have been studied using spiked wine (the amount of the volatiles that was previously determined) with known amounts of the standards. Thus, one wine sample containing known amounts of the added volatile compounds was extracted five subsequent times (in 1 day) applying the extraction procedure described above, and the extracts were analyzed by GC-MS in order to study the intraday repeatability. Furthermore, the spiked wine was extracted three times during three consecutive days in order to study the interday reproducibility. In order to avoid the presence of oxygen in the wine analyzed during these 3 days, it was divided into three bottles of $250 \mathrm{~mL}$ and stored at $4{ }^{\circ} \mathrm{C}$ in darkness, closed with caps. Each bottle was opened before analysis.

\section{Statistical Analysis}

Statistical analysis included calculation of means and standard deviations for each of the 33 detected volatile compounds, which was performed by Excel 2007.

\section{Results and Discussion}

The method for determination of volatiles in wine was developed starting from selection of reference compounds based on literature data for the expected compounds, their grouping in the suitable groups: alcohols, esters, aldehydes, lactones, terpenes, and phenols and then deciding on the standards for calibration. For quantification of alcohols, 2-phenyl ethanol, the most important phenol-derived higher alcohol was used, ethyl nonanoate for the esters, and butyrolactone and tyrosol were used for analysis of these specific wine aroma compounds. Since the extraction step was essential for separation of the volatile fraction from the wine complex matrix, it was necessary to decide on the internal standard that would be suitable for the large and diverse group of target compounds. Since previous studies suggest that alcohols are the dominant fraction (Tao et al. 2008), 1-octanol was chosen as the most suitable because it is similar to the expected ones, but not present in wine. As for the liquid-liquid extraction procedure, the solvent dichloromethane and the volumes of the sample and extraction solvents were optimized following previous analogous studies (Andujar-Ortiz et al. 2009).

\section{Method Validation}

The linearity data of the analytical method are presented in Table 1. As can be seen from Table 1, the linearity is satisfactory in all cases with correlation coefficients $\left(R^{2}\right)$ ranging from 0.9951 (tyrosol) to 0.9992 (2-phenyl ethanol).

Table 1 Linear regression data

\begin{tabular}{lcccc}
\hline Compound & Intercept & Slope & $R^{2}$ & Range $(\mu \mathrm{g} / \mathrm{L})$ \\
\hline 2-Phenyl ethanol & -1.2582 & 0.0179 & 0.9992 & $50-15,000$ \\
Ethyl nonanoate & -0.0641 & 0.0138 & 0.9953 & $50-20,000$ \\
Butyrolactone & -0.1314 & 0.0009 & 0.9961 & $100-20,000$ \\
Tyrosol & -1.2787 & 0.0172 & 0.9951 & $100-5,000$ \\
\hline
\end{tabular}


Table 2 Limit of quantification of 2-phenyl ethanol, ethyl nonanoate, butyrolactone, and tyrosol

\begin{tabular}{|c|c|c|c|c|c|c|c|c|}
\hline \multirow{2}{*}{$\begin{array}{l}\text { Analysis } \\
\text { (days) }\end{array}$} & \multicolumn{2}{|c|}{ 2-Phenyl ethanol } & \multicolumn{2}{|c|}{ Ethyl nonanoate } & \multicolumn{2}{|l|}{ Butyrolactone } & \multicolumn{2}{|l|}{ Tyrosol } \\
\hline & $\begin{array}{l}\text { Found } \\
\text { concentration } \\
(\mu \mathrm{g} / \mathrm{L})\end{array}$ & $\begin{array}{l}\text { Relative } \\
\text { error (\%) }\end{array}$ & $\begin{array}{l}\text { Found } \\
\text { concentration } \\
(\mu \mathrm{g} / \mathrm{L})\end{array}$ & $\begin{array}{l}\text { Relative } \\
\text { error (\%) }\end{array}$ & $\begin{array}{l}\text { Found } \\
\text { concentration } \\
(\mu \mathrm{g} / \mathrm{L})\end{array}$ & $\begin{array}{l}\text { Relative } \\
\text { error (\%) }\end{array}$ & $\begin{array}{l}\text { Found } \\
\text { concentration } \\
(\mu \mathrm{g} / \mathrm{L})\end{array}$ & $\begin{array}{l}\text { Relative } \\
\text { error (\%) }\end{array}$ \\
\hline 1 & 48.4 & -3.2 & 51.6 & 3.2 & 104 & 4 & 98.3 & -1.7 \\
\hline 2 & 50.7 & 1.4 & 50.4 & 0.8 & 102 & 2 & 103 & 3 \\
\hline 3 & 51.2 & 2.4 & 48.5 & -3 & 98.6 & -1.4 & 104 & 4 \\
\hline 4 & 49.6 & -0.8 & 53.2 & 6.4 & 103 & 3 & 103 & 3 \\
\hline 5 & 52.4 & 4.8 & 52.4 & 4.8 & 102 & 2 & 97.6 & -2.4 \\
\hline$<x>$ & 50.5 & 0.92 & 51.2 & 2.44 & 102 & & 101 & \\
\hline SD & 1.53 & & 1.84 & & 2.03 & & 2.99 & \\
\hline RSD & 3.03 & & 3.59 & & 1.99 & & 2.95 & \\
\hline
\end{tabular}

The LOQ was determined for the four analytes: 2-phenyl ethanol, ethyl nonanoate, butyrolactone, and tyrosol by measuring the lowest concentration calibration standards in five analytical days and calculating the errors of the measurement. The results for the LOQ values were taken as the lowest concentrations because satisfactory values were obtained for the relative error for all four analytes (relative error $<6.4 \%$ ). The results from these analyses are presented in Table 2.

The accuracy of the procedure was checked using the standard addition method. One wine sample, Kékfrankos (sample no. 1), was spiked with appropriate volumes of the standard solutions of 2-phenyl ethanol, ethyl nonanoate, butyrolactone, and tyrosol with concentrations of 50,200 , and $500 \mu \mathrm{g} / \mathrm{L}$ for each standard.
The satisfactory results for the recovery ranging from 92.2 to $103 \%$ (Table 3 ) confirmed that the method is accurate and convenient for quantitative analysis. Additionally, to confirm the accuracy of the method and to check repeatability, five replicated extractions on an actual wine sample (1) have been performed within 1 day. Every extract was injected three times into the gas chromatograph. The relative standard deviations (RSD) of the five replicate samples for each compound are presented in Table 4, showing satisfactory values for the RSD. Reproducibility was also checked with replicate samples analyzed in three different days (3 replicates $\times 3$ injections $\times 3$ days), and the RSD for each volatile compound was calculated (Table 4). Accordingly, the method showed good repeatability and reproducibility,
Table 3 Standard additions for checking the accuracy of the extraction procedure and the $\mathrm{GC}-$ MS method for determination of volatile compounds in wine samples $(n=3)$
${ }^{a}$ Values are average of three replicates

$R S D$ relative standard deviation, (\%)

\begin{tabular}{|c|c|c|c|c|c|}
\hline $\begin{array}{l}\text { Concentration } \\
\text { in wine }(\mu \mathrm{g} / \mathrm{L})\end{array}$ & $\begin{array}{l}\text { Standard additions } \\
(\mu \mathrm{g} / \mathrm{L})\end{array}$ & $\begin{array}{l}\text { Calculated } \\
(\mu \mathrm{g} / \mathrm{L})\end{array}$ & $\begin{array}{l}\text { Experimentally } \\
\text { found }^{\mathrm{a}}(\mu \mathrm{g} / \mathrm{L})\end{array}$ & RSD (\%) & Recovery (\%) \\
\hline & 2-Phenyl ethanol & & & & \\
\hline \multirow[t]{4}{*}{14,170} & 50.0 & 14,220 & 14,372 & 3.18 & 101 \\
\hline & 200 & 14,370 & 14,178 & 2.04 & 98.7 \\
\hline & 500 & 14,670 & 14,516 & 8.29 & 99.0 \\
\hline & Ethyl nonanoate & & & & \\
\hline \multirow[t]{4}{*}{ / } & 50.0 & 50.0 & 51.1 & 1.31 & 102 \\
\hline & 200 & 200 & 206 & 1.23 & 103 \\
\hline & 500 & 500 & 507 & 9.46 & 101 \\
\hline & Butyrolactone & & & & \\
\hline \multirow[t]{4}{*}{8,150} & 50.0 & 8,250 & 8,126 & 1.46 & 98.5 \\
\hline & 200 & 8,400 & 8,561 & 3.69 & 102 \\
\hline & 500 & 8,700 & 8,577 & 6.11 & 98.6 \\
\hline & Tyrosol & & & & \\
\hline \multirow[t]{3}{*}{1,480} & 50.0 & 1,530 & 1,577 & 3.01 & 91.7 \\
\hline & 200 & 1,680 & 1,658 & 4.57 & 93.8 \\
\hline & 500 & 1,980 & 1,975 & 2.03 & 92.2 \\
\hline
\end{tabular}


Table 4 Results for repeatability and reproducibility data for each compound (numbers correspond to peak numbers in Fig. 1)

\begin{tabular}{|c|c|c|c|c|c|c|c|}
\hline \multirow[t]{2}{*}{ Number } & \multirow[t]{2}{*}{$\begin{array}{l}\text { Volatile compounds of } \\
\text { Kékfrankos wine (1) }\end{array}$} & \multirow[t]{2}{*}{$t_{\mathrm{R}} / \min$} & \multirow[t]{2}{*}{ LRI } & \multicolumn{2}{|c|}{ Repeatability (5 replicates) } & \multicolumn{2}{|c|}{$\begin{array}{l}\text { Reproducibility ( } 3 \text { replicates } \times 3 \\
\text { injections } \times 3 \text { days) }\end{array}$} \\
\hline & & & & $\begin{array}{l}\text { Mean concentration } \\
(\mu \mathrm{g} / \mathrm{L})\end{array}$ & RSD (\%) & $\begin{array}{l}\text { Mean concentration } \\
(\mu \mathrm{g} / \mathrm{L})\end{array}$ & $\operatorname{RSD}(\%)$ \\
\hline 1 & Ethyl propanoate & 5.47 & 954.5 & 104 & 3.15 & 103.2 & 0.59 \\
\hline 2 & Ethyl isobutyrate & 5.66 & 963.5 & 82.3 & 5.8 & 82.8 & 0.91 \\
\hline 3 & 3-Heptanol & 6.09 & $1,011.1$ & 575 & 0.42 & 575 & 0.18 \\
\hline 4 & Ethyl butanoate & 6.85 & $1,033.8$ & 156 & 5.08 & 157 & 4.27 \\
\hline 5 & Isobuty alcohol & 8.58 & $1,089.2$ & 840 & 1.94 & 853 & 3.28 \\
\hline 6 & Isoamyl acetate & 9.83 & $1,122.4$ & 136 & 1.89 & 142 & 2.30 \\
\hline 7 & Butyl formate & 10.59 & $1,140.9$ & 111 & 2.20 & 109 & 2.24 \\
\hline 8 & 1-Pentanol & 13.24 & $1,209.7$ & 11,600 & 9.50 & 11,561 & 1.63 \\
\hline 9 & Ethyl caproate & 14.33 & $1,233.9$ & 155 & 1.88 & 148 & 0.12 \\
\hline 10 & 1-Butamine, N-nitro & 16.65 & $1,343.5$ & 1,353 & 7.22 & 1,368 & 1.41 \\
\hline 11 & 1-Hexanol & 19.02 & $1,351.8$ & 743 & 0.25 & 745 & 0.78 \\
\hline 12 & E-3-Hexanol & 19.34 & $1,361.5$ & 567 & 0.07 & 565 & 0.04 \\
\hline 13 & Ethyl caprylate & 22.85 & $1,434.3$ & 199 & 1.81 & 186 & 1.34 \\
\hline 14 & Ethyl-3-hydroxybutanoate & 25.04 & $1,514.8$ & 117 & 3.93 & 120 & 2.52 \\
\hline 15 & 2,3-Butanediol & 26.26 & $1,539.4$ & 280 & 8.48 & 285 & 0.87 \\
\hline 16 & 1,3-Butylenglycol & 27.72 & $1,577.2$ & 598 & 0.49 & 599 & 0.48 \\
\hline 17 & Butyrolactone & 30.35 & $1,618.3$ & 8,150 & 1.07 & 8,162 & 2.08 \\
\hline 18 & Ethyl caprinate & 30.79 & $1,638.3$ & 90.3 & 10.0 & 87.5 & 4.36 \\
\hline 19 & Diethyl succinate & 32.35 & $1,677.5$ & 2,861 & 1.27 & 2,893 & 0.63 \\
\hline 20 & 3-(Methylthio)-1-propanol & 33.68 & $1,711.7$ & 713 & 0.49 & 711 & 0.53 \\
\hline 21 & Phenyl ethyl acetate & 36.93 & $1,810.4$ & 81.5 & 4.26 & 82.3 & 2.35 \\
\hline 22 & N-(3-methylbutyl)acetamide & 38.95 & $1,861.7$ & 109 & 3.93 & 105.6 & 2.63 \\
\hline 23 & Benzyl alcohol & 39.31 & $1,871.3$ & 738 & 0.41 & 740 & 0.51 \\
\hline 24 & Phenyl ethanol & 40.44 & $1,905.2$ & 14,170 & 5.26 & 14,165 & 5.12 \\
\hline 25 & Diethyl malate & 41.81 & $2,042.3$ & 270 & 6.4 & 281 & 1.21 \\
\hline 26 & Octanoic acid & 44.85 & $2,111.3$ & 520 & 5.20 & 518 & 6.42 \\
\hline 27 & Acetyl glycine ethyl ester & 46.11 & $2,153.1$ & 89.5 & 4.04 & 90.3 & 2.78 \\
\hline 28 & $\begin{array}{l}\text { Succinic acid, 2-hydroxy-3- } \\
\text { methyl-diethylester }\end{array}$ & 48.53 & $2,163.1$ & 444 & 0.47 & 438 & 4.34 \\
\hline 29 & Vinyl guiacol & 49.48 & $2,193.1$ & 103 & 3.58 & 102 & 4.81 \\
\hline 30 & $\begin{array}{l}\text { 5-Oxotetrahydrofuran-2-caboxylic } \\
\text { acid ethyl ester }\end{array}$ & 50.44 & $2,233.3$ & 402 & 1.34 & 396 & 3.68 \\
\hline 31 & Decanoic acid & 51.92 & $2,336.5$ & 201 & 1.62 & 210 & 0.27 \\
\hline 32 & Dihydrobenzo furan & 52.64 & $2,398.2$ & 1,500 & 3.43 & 1,513 & 1.87 \\
\hline 33 & Tyrosol & 57.03 & $2,249.5$ & 1,480 & 3.43 & 1,476 & 2.77 \\
\hline
\end{tabular}

LRI linear retention index calculated using C10-C24 n-alkanes series, $R S D$ relative standard deviation, (\%)

and the values for RSD were $<10 \%$ (most of the values were $<5 \%)$.

\section{Method Application}

The method was then applied for analysis of the volatile composition of five wine samples from the Kékfrankos variety, and a total of 33 volatile compounds were identified and quantified in these red wines from the Villány region, Hungary, for the first time. The compounds, grouped in chemical classes, are presented in
Table 5. A total ion chromatogram of one Kékfrankos wine is presented in Fig. 1.

Overall, 12 alcohols have been identified in the Kékfrankos wines (Table 5) with a total alcohol amount of 32.3, $14.4,69.5,0.59$, and $4.3 \mathrm{mg} / \mathrm{L}$ for the five wines (1), (2) (3), (4), and (5), respectively. This volatile fraction was mainly composed of 2-phenyl ethanol, the most important phenol-derived higher alcohol (present from 11.7 to $43.7 \%$ of the total alcohols), and 1-pentanol (26-57\% of the total alcohols) as the major components in the overall volatile content of the wines. The other important 
Table 5 Concentrations of volatile compounds (microgram per liter) in the studied samples (1-5) of Kékfrankos wines (numbers correspond to peak numbers in Fig. 1)

\begin{tabular}{|c|c|c|c|c|c|c|}
\hline \multicolumn{2}{|c|}{$\begin{array}{l}\text { Volatile compounds in } \\
\text { Kékfrankos wines samples }\end{array}$} & $\begin{array}{l}\text { (1) Concentration } \\
(\mu \mathrm{g} / \mathrm{L})\end{array}$ & $\begin{array}{l}\text { (2) Concentration } \\
(\mu \mathrm{g} / \mathrm{L})\end{array}$ & $\begin{array}{l}\text { (3) Concentration } \\
(\mu \mathrm{g} / \mathrm{L})\end{array}$ & $\begin{array}{l}\text { (4) Concentration } \\
(\mu \mathrm{g} / \mathrm{L})\end{array}$ & $\begin{array}{l}\text { (5) Concentration } \\
(\mu \mathrm{g} / \mathrm{L})\end{array}$ \\
\hline \multicolumn{7}{|c|}{ Alcohols $^{\mathrm{a}}$} \\
\hline 11 & 1-Hexanol & $743 \pm 0.25$ & $1,578 \pm 5.63$ & $676.70 \pm 1.72$ & $29.15 \pm 4.27$ & $43.84 \pm 5.52$ \\
\hline 8 & 1-Pentanol & $11,600 \pm 9.50$ & $80,232 \pm 5.53$ & $39,895.3 \pm 4$ & $161.77 \pm 0.24$ & $1,125.38 \pm 1.81$ \\
\hline 16 & 1,3-Butylen glycol & $598 \pm 0.49$ & $2,503 \pm 6.49$ & $1,176.10 \pm 2.20$ & $4.34 \pm 0.38$ & $32.39 \pm 1.97$ \\
\hline 15 & 2,3-Butanediol & $280 \pm 8.48$ & $147 \pm 29.88$ & 1 & l & $9.85 \pm 20.52$ \\
\hline 3 & 3-Heptanol & $575 \pm 0.42$ & $346 \pm 27.1$ & $329.23 \pm 3.16$ & $6.01 \pm 1.77$ & $5.12 \pm 1.42$ \\
\hline 20 & 3-(Methylthio)-1-propanol & $713 \pm 0.49$ & $723 \pm 3.93$ & $452.34 \pm 3.47$ & $15.76 \pm 2.01$ & $16.00 \pm 2.23$ \\
\hline 23 & Benzyl alcohol & $738 \pm 0.41$ & $1,079 \pm 4.14$ & $8,019.63 \pm 165$ & $85.11 \pm 8.69$ & $900.98 \pm 99.21$ \\
\hline 12 & E-3-Hexanol & $567 \pm 0.07$ & $240 \pm 5.12$ & $197.84 \pm 8.28$ & $3.90 \pm 1.80$ & $7.35 \pm 3.82$ \\
\hline 5 & Isobutyl alcohol & $840 \pm 1.94$ & $2,728 \pm 4.62$ & $1,245.27 \pm 2.97$ & $25.88 \pm 1.36$ & $22.99 \pm 1.59$ \\
\hline 24 & Phenyl ethanol & $14,170 \pm 5.26$ & $50,983 \pm 7.62$ & $15,412.94 \pm 85.4$ & $69.84 \pm 0.20$ & $1,826.87 \pm 4.11$ \\
\hline 33 & Tyrosol & $1,480 \pm 3.43$ & $3,248 \pm 9.21$ & $1,794.19 \pm 6.14$ & $180.11 \pm 8.28$ & $310.51 \pm 9.34$ \\
\hline \multirow[t]{2}{*}{29} & Vinyl guiacol & $103 \pm 3.58$ & $209 \pm 16.84$ & $323.98 \pm 143.4$ & $14.46 \pm 6.75$ & $33.30 \pm 12.47$ \\
\hline & Total alcohols $(\mu \mathrm{g} / \mathrm{L})$ & $32,407 \pm 30.3$ & $144,016 \pm 126$ & $69,522 \pm 425$ & $596 \pm 35.7$ & $4,335 \pm 164$ \\
\hline \multicolumn{7}{|c|}{ Esters $^{\mathrm{b}}$} \\
\hline 30 & $\begin{array}{l}\text { 5-Oxotetrahydrofuran-2-caboxylic } \\
\text { acid ethyl ester }\end{array}$ & $402 \pm 1.34$ & $763 \pm 6.92$ & $631.75 \pm 49.67$ & $30.85 \pm 4.88$ & $59.66 \pm 6.29$ \\
\hline 27 & Acetyl glycine ethyl ester & $89.5 \pm 4.04$ & $2,065 \pm 8.01$ & $979.08 \pm 36.24$ & $106.77 \pm 16.54$ & $24.42 \pm 2.75$ \\
\hline 7 & Butyl formate & $111 \pm 2.20$ & $48.7 \pm 32.17$ & $16.99 \pm 41.19$ & 1 & $15.77 \pm 21.13$ \\
\hline 25 & Diethyl malate & $270 \pm 2.1$ & 1 & $35.26 \pm 3.31$ & $21.58 \pm 4.46$ & 1 \\
\hline 19 & Diethyl succinate & $2,861 \pm 1.27$ & $8,105 \pm 9.82$ & $17,420.90 \pm 0.86$ & $47.67 \pm 0.58$ & $1,189.64 \pm 4.36$ \\
\hline 14 & Ethyl-3-hydroxybutanoate & $117 \pm 3.93$ & $216 \pm 116.96$ & $36.48 \pm 79.66$ & $12.57 \pm 8.76$ & $9.42 \pm 4.15$ \\
\hline 4 & Ethyl butanoate & $156 \pm 5.08$ & $438 \pm 11.62$ & $985.67 \pm 147.26$ & $17.98 \pm 10.76$ & $13.73 \pm 6.01$ \\
\hline 18 & Ethyl caprinate & $90.3 \pm 10.0$ & $119 \pm 18.66$ & $92.36 \pm 9.42$ & 1 & $19.94 \pm 10.67$ \\
\hline 9 & Ethyl caproate & $155 \pm 1.88$ & $284 \pm 5.46$ & $146.30 \pm 6.16$ & $20.46 \pm 22.75$ & $16.37 \pm 11.69$ \\
\hline 13 & Ethyl caprylate & $199 \pm 1.81$ & $509 \pm 4.06$ & $128.32 \pm 6.84$ & $7.30 \pm 9.52$ & $5.10 \pm 2.28$ \\
\hline 2 & Ethyl isobutyrate & $82.3 \pm 5.8$ & $252 \pm 19.14$ & $84.48 \pm 23.61$ & $7.96 \pm 14.53$ & $15.13 \pm 14.46$ \\
\hline 1 & Ethyl propanoate & $104 \pm 3.15$ & $924 \pm 7.69$ & $416.84 \pm 2.61$ & $21.22 \pm 5.09$ & $13.23 \pm 2.43$ \\
\hline 6 & Isoamyl acetate & $136 \pm 1.89$ & $335 \pm 5.23$ & I & $19.27 \pm 24.91$ & $14.57 \pm 31.00$ \\
\hline 21 & Phenyl ethyl acetate & $81.5 \pm 4.26$ & $4,270 \pm 3.42$ & $1,86.59 \pm 101.70$ & $26.61 \pm 2.89$ & $36.47 \pm 6.92$ \\
\hline \multirow[t]{2}{*}{28} & $\begin{array}{l}\text { Succinic acid, 2-hydroxy-3- } \\
\text { methyl-diethylester }\end{array}$ & $444 \pm 0.47$ & $1,089 \pm 8.82$ & $899.16 \pm 82.09$ & $26.90 \pm 4.64$ & $67.85 \pm 4.55$ \\
\hline & Total esters $(\mu \mathrm{g} / \mathrm{L})$ & $5,298 \pm 49.2$ & $19,417 \pm 258$ & $22,060 \pm 588$ & $367 \pm 180$ & $1,500 \pm 129$ \\
\hline \multicolumn{7}{|c|}{ Fatty acids ${ }^{\mathrm{a}}$} \\
\hline 31 & Decanoic acid & $201 \pm 1.62$ & $453 \pm 4.66$ & $268.93 \pm 57.28$ & $19.38 \pm 4.81$ & $169.62 \pm 22.43$ \\
\hline \multirow[t]{2}{*}{26} & Octanoic acid & $520 \pm 5.20$ & $868 \pm 2.91$ & $978.15 \pm 4.45$ & $63.75 \pm 32.80$ & $29.00 \pm 7.37$ \\
\hline & Total acids $(\mu \mathrm{g} / \mathrm{L})$ & $721 \pm 6.82$ & $1,321 \pm 7.57$ & $1,247 \pm 61.7$ & $83.1 \pm 37.6$ & $198 \pm 29.8$ \\
\hline \multicolumn{7}{|c|}{ Furans $^{\mathrm{a}}$} \\
\hline 32 & Dihydrobenzo furan & $1,500 \pm 3.43$ & $641 \pm 22.5$ & $220 \pm 38.9$ & $39.7 \pm 10.6$ & $457 \pm 111$ \\
\hline \multicolumn{7}{|c|}{ Lactones } \\
\hline 17 & Butyrolactone & $8,150 \pm 1.07$ & $19,542 \pm 5.05$ & $14,360 \pm 1.27$ & $277 \pm 1.42$ & $839 \pm 4.37$ \\
\hline \multicolumn{7}{|c|}{ Other compounds ${ }^{\mathrm{a}}$} \\
\hline 10 & 1-Butamine, $\mathrm{N}$-nitro & $1,353 \pm 7.22$ & $6,307 \pm 7.01$ & $3,905 \pm 0.99$ & $57.0 \pm 1.56$ & $164.1 \pm 3.32$ \\
\hline \multirow[t]{3}{*}{22} & $\mathrm{~N}$-(3-methylbutyl)acetamide & $109 \pm 3.93$ & $5,524 \pm 6.92$ & $229 \pm 191$ & $23.0 \pm 2.17$ & $1,015 \pm 90.6$ \\
\hline & Total other compounds $(\mu \mathrm{g} / \mathrm{L})$ & $1,462 \pm 11.2$ & $11,831 \pm 13.9$ & $4,133 \pm 192$ & $80.1 \pm 3.73$ & $1,179 \pm 93.8$ \\
\hline & Total volatiles $(\mu \mathrm{g} / \mathrm{L})$ & $49,786 \pm 101$ & $79,206 \pm 330$ & $59,061 \pm 1,111$ & $1,317 \pm 263$ & $5,448 \pm 439$ \\
\hline
\end{tabular}

\footnotetext{
${ }^{a}$ Expressed in equivalents of phenyl ethanol

${ }^{\mathrm{b}}$ Expressed in equivalents of ethyl nonanoate

Concentration in microgram per liter \pm RSD (relative standard deviation, (\%))

Bold numbers indicate the total amount of each group of volatile compounds
} 
Fig. 1 GC/MS chromatogram of the volatile compounds in Kékfrankos wine (sample 1). Peak numbers refer to the compounds listed in Tables 4 and 5

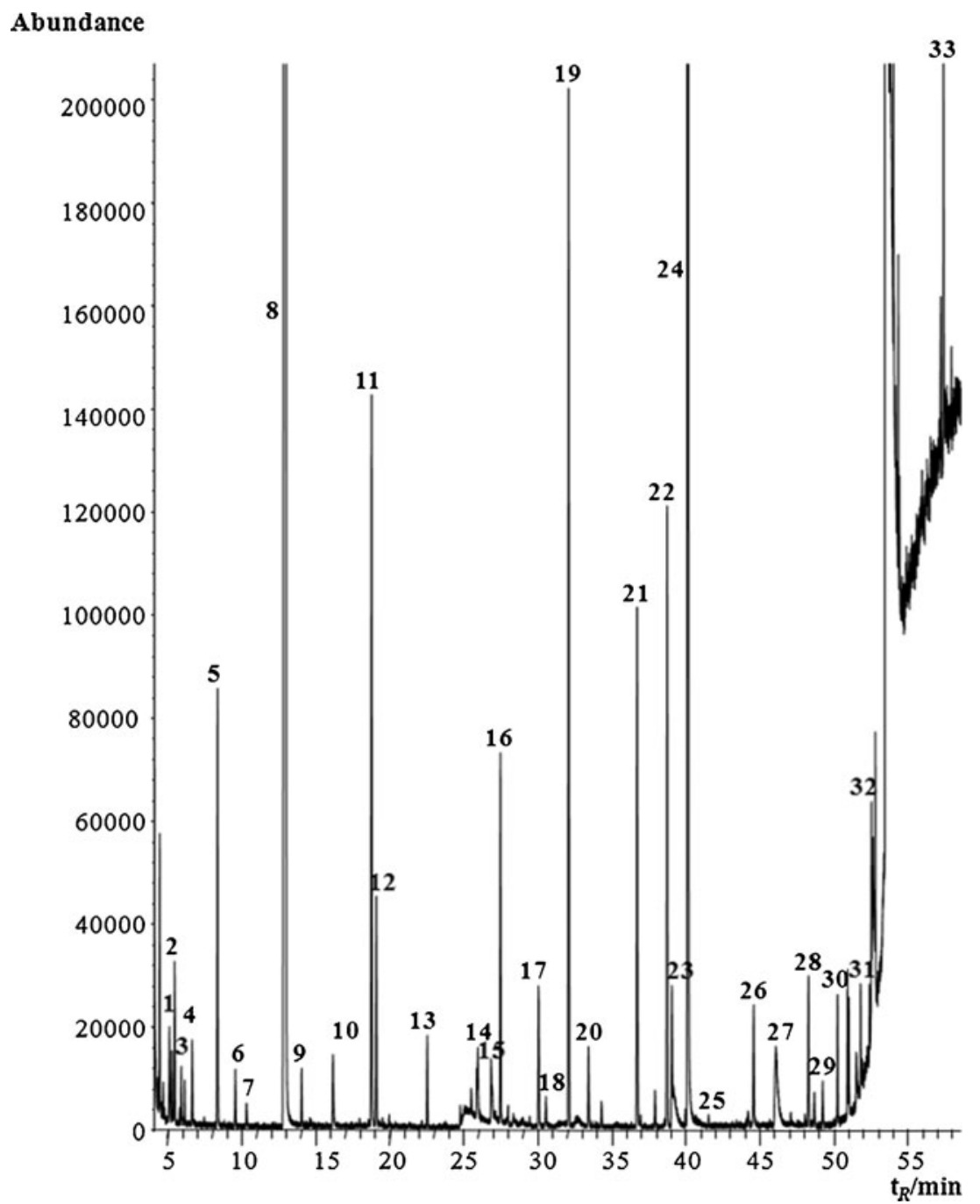

alcohol, detected in a considerable amount in the Kékfrankos wines, was tyrosol, comprising 2-7\% of the total alcohols in four wines, except for wine (4) which contained $30 \%$ tyrosol of the total alcohols in the wine. Isobutyl alcohol was also found in the wine, which is formed during the catabolic pathway from its corresponding amino acid, valine (Li et al. 2008). In addition, all Kékfrankos wines presented higher content of alcohols compared to Cabernet Sauvignon wines from Changli County (China) (Tao et al. 2008), while three wines, (1), (2), and (3), had a higher amount of alcohols compared to Tempranillo wines (Castro-Vázquez et al. 2011), but a lower amount compared to Albarello and Brancellao wines (Cortés and Díaz, 2011) as well as from the varieties Ribolla Gialla and Malvasia Istriana (Bavčar et al. 2011).

Another important family of aroma compounds in wine are the esters. In our study, 15 esters were identified and quantified in the analyzed wines (Table 5), present from 0.36 to $22 \mathrm{mg} / \mathrm{L}$ total content of esters. The main contributor to this class of volatile compounds was diethyl succinate which comprised 13-54 \% of the total amount of esters found in wines (1), (2), and (4), and $79 \%$ in wines (3) and (5).
Diethyl succinate possesses fruity aromatic impact, affecting the overall wine aroma characteristics. The acetate esters, such as phenylethyl acetate and isoamyl acetate, possessing sensory impact described as "banana and apple", were also detected in the wine (except in wine (3) which did not contain isoamyl acetate). Overall, Kékfrankos wines possessed a similar amount of total esters in comparison to other red wines (Qian et al. 2009, Bavčar et al. 2011, Castro-Vázquez et al. 2011).

Butyrolactone was the only compound that was detected from this group, found in a relatively high concentration (15-25\% from all volatiles) (Table 5). Its content depends on grape variety, maceration, and aging (Bueno et al. 2003). Volatile components belonging to the group of fatty acids, such as octanoic and decanoic acids, were also detected and quantified in the wine (Table 5).

\section{Conclusion}

A method for analysis of volatiles in wine using liquidliquid extraction with dichloromethane and GC-MS for 
separation and detection has been developed and validated. The method of validation confirmed its satisfactory linearity, LOQ, accuracy, repeatability, and reproducibility. It was then used for determination of 33 volatile compounds in the red Kékfrankos wines produced in Hungary.

Acknowledgments This work was supported by a grant from the CEEPUS, CII-HU-0010-03-0809 Network, covering the study stay of V.I. in Pécs, Hungary where the analyses were performed.

\section{References}

Andujar-Ortiz I, Moreno-Arribas MV, Martín-Álvarez PJ, Pozo-Bayón MA (2009) J Chromatogr A 1216:7351
Bavčar D, Česnik HB, Čuš F, Košmerl T (2011) Int J Food Sci Tech 46:1801

Bueno JE, Peinado R, Moreno J, Medina M, Moyano L, Zea L (2003) J Food Sci 68:158

Castro-Vázquez L, Elena Alãnón M, Calvo E, Jesús Cejudo M, DíazMaroto MC, Pérez-Coello MS (2011) J Chromatogr A 1218:4910

Cortés S, Díaz E (2011) J Food Compos Anal 24:154

Li H, Tao YS, Wang H, Zhang L (2008) Eur Food Res Technol $227: 287$

Marais J, Poll HJ (1980) Vitis 19:151

Ortega-Heras M, González-SanJosé ML, Beltrán S (2002) Anal Chim Acta 458:85

Qian MC, Fang Y, Shellie K (2009) J Agric Food Chem 57:7459

Tao Y, Li H, Wang H, Zhang L (2008) J Food Compos Anal 21:689

Tang Y-J, Wang G, Li Y-Y, Li H-M, Tang Y, Liu P (2011) Food Anal Methods doi:10.1007/s12161-011-9293-2, in press

Verzera A, Ziino M, Scacco A, Lanza CM, Mazzaglia A, Romeo V, Condurso C (2008) Food Anal Methods 1:144 